\title{
IDENTIFIKASI METABOLIT SEKUNDER, UJI TOKSISITAS DAN UJI AKTIVITAS ANTIOKSIDAN EKSTRAK DAUN GAMAL (Gliricidia sepium)
}

\author{
Ninin Kartika Ulfa ${ }^{\mathbf{1}}$, Aditya Fridayanti ${ }^{\mathbf{1}}$ Vina Maulidya $^{\mathbf{1}}$, dan Laode Rijai ${ }^{\mathbf{1}}$ \\ ${ }^{1}$ Laboraturium Penelitian dan Pengembangan FARMAKA TROPIS \\ Fakultas Farmasi Universitas Mulawarman, Samarinda, Kalimantan Timur \\ *email: nininkartikaulfa@gmail.com
}

\begin{abstract}
ABSTRAK
Gliricidia sepium merupakan tanaman dari famili Fabaceae yang secara tradisional dimanfaatkan sebagai obat luar ruam kulit, demam, dan gangren. Tujuan dari penelitian ini adalah untuk mengetahui kandungan metabolit sekunder, untuk mengetahui toksisitas dan aktivitas antioksidan dari ekstrak daun gamal (G. sepium). Hasil skrining fitokimia pada ekstrak etanol positif mengandung alkaloid, saponin, fenolik, tanin, dan steroid. Pada fraksi n-heksan positif mengandung alkaloid dan steroid serta pada fraksi etil asetat positif mengandung alkaloid, saponin, fenolik, dan tanin. Metode uji toksisitas yang digunakan adalah Brine Shrimp Lethality Test (BSLT) dengan penentuan nilai LC $_{50}$ menggunakan analisa probit. Berdasarkan hasil pengujian diperoleh nilai $\mathrm{LC}_{50}$ ekstrak etanol $409.5 \mathrm{ppm}$, fraksi n-heksan $350.63 \mathrm{ppm}$ dan fraksi etil asetat $463.15 \mathrm{ppm}$. Metode uji aktivitas antioksidan yang digunakan adalah metode peredaman DPPH. Berdasarkan uji aktivitas antioksidan ekstrak dan fraksi diperoleh hasil nilai $\mathrm{IC}_{50}$ ekstrak etanol, fraksi n-heksan dan fraksi etil asetat berturut-turut adalah $350.1 \mathrm{ppm}, 784,98 \mathrm{ppm}$ dan 166,6 ppm. Dari data tersebut dapat ditafsirkan bahwa fraksi etil asetat mempunyai aktivitas antioksidan lebih baik.
\end{abstract}

Kata kunci: Gliricidia sepium, metabolit sekunder, Toksisitas, BSLT, Antioksidan, DPPH

\begin{abstract}
Gliricidia sepium is a plant of the Fabaceae family that was traditionally used as a topical drug of a skin rash, fever, and gangrene. The purpose of this research was to determine the content of secondary metabolites, to determine the toxicity and antioxidant activity of the extracts of leaves of Gliricidia sepium. The results of phytochemical screening positive on ethanol extracts contain alkaloids, saponins, phenolic, tannins and steroids. On the fraction of n-hexane containing alkaloids and steroids. On the ethyl acetate fraction containing alkaloids, saponins, phenolic, and tannins. The toxicity test method used Brine Shrimp Lethality Test (BSLT) and to determine LC $C_{50}$ value using probit analysis. Based on test obtained the $L C_{50}$ value of ethanol extract $409.5 \mathrm{ppm}, n$-hexane fraction $350.63 \mathrm{ppm}$ and ethyl acetate fraction $463.15 \mathrm{ppm}$. The test method used is the antioxidant activity is DPPH method. Based on the test the antioxidant activity of extracts and fractions obtained results $I C_{50}$ value of the ethanol extract, $n$-hexane fraction and fraction of ethyl acetate are 350, 1 ppm, 784,98 ppm and 166,6 ppm. From these data it can be interpreted that the ethyl acetate fraction has better activity.
\end{abstract}

Keywords: Gliricidia sepium, secondary metabolites, toxicity, BSLT, antioxidant, DPPH 


\section{PENDAHULUAN}

Indonesia adalah negara dengan hutan tropis paling besar ketiga di dunia (setelah Brazil dan Zaire). Keanekaragaman hayati merupakan basis berbagai pengobatan dan penemuan industri farmasi dimasa mendatang. Jumlah tumbuhan berkhasiat obat di Indonesia diperkirakan sekitar 1.260 jenis tumbuhan. Tumbuhan menghasilkan metabolit sekunder yang berpotensi sebagai antioksidan, zat perwarna, penambah aroma makanan, parfum, insektisida dan obat (Yuhernita, 2011).

Salah satu tumbuhan yang tumbuh di hutan Kalimantan adalah tumbuhan gamal (Gliricidia sepium). Tanaman ini belum dilakuakan penelitian secara ilmiah mengenai manfaatnya dalam pengobatan. Namun menurut Menurut Orwa et, al. (2009) daun gamal terbukti mempunyai aktivitas sebagai antijamur. Dilaporkan berkhasiat ekspektoran, obat penenang dan supuratif. Dan sebagai obat tradisional digunakan untuk alopecia, bisul, memar, luka bakar, kelemahan, erisipelas, demam, patah tulang, gangren, sakit kepala, gatal, biang keringat, rematik, tumor kulit, urtikaria dan luka. Dari itu dilakukan penelitian pendahuluan ini untuk mengetahui aktivitas dari senyawa yang terkandung dalam daun gamal. Pengujian yang dilakukan adalah pengujian metabolit sekunder, uji aktivitas antioksidan dan uji toksisitas.

Senyawa metabolit sekunder merupakan senyawa kimia yang umumnya mempunyai kemampuan bioaktivitas dan berfungsi sebagai pelindung tumbuhan dari gangguan hama penyakit untuk tumbuhan itu sendiri atau lingkungannya. Senyawa kimia sebagai hasil metabolit sekunder telah banyak digunakan untuk zat warna, racun, aroma makanan, obatobatan dan sebagainya. Banyak jenis tumbuh-tumbuhan yang digunakan sebagai obatobatan dikenal sebagai obat tradisional, sehingga perlu dilakukan penelitian tentang penggunaan tumbuh-tumbuhan berkhasiat dan mengetahui senyawa kimia yang bermanfaat sebagai obat (Setiana, 2011).

Antioksidan adalah penghambat adanya radikal bebas yang dapat merusak sel-sel makhluk hidup akibat kondisi oksidasi dan ketidakseimbangan radikal bebas yang menyebabkan gangguan terhadap metabolisme dalam sel. Radikal bebas adalah spesies yang tidak stabil karena memiliki elektron yang tidak berpasangan dan mencari pasangan elektron dalam makromolekul biologi. Protein, lipida, dan DNA dari sel manusia yang sehat merupakan sumber pasangan elektron yang baik. Kondisi oksidasi dapat menyebabkan kerusakan protein dan DNA, kanker, penuaan, dan penyakit lainnya (Ozyurt et al., 2008).

Berbagai metode digunakan untuk mengukur aktivitas antioksidan produk makanan, dapat memberikan hasil yang bervariasi tergantung pada keberadaan radikal bebas tertentu yang digunakan sebagai reaktan. Metode yang digunakan pada penentuan aktivitas antioksidan ekstrak daun gamal (Gliricidia sepium) pada penelitian ini adalah metode DPPH. Metode ini dipilih karena memiliki beberapa kelebihan seperti teknis simpel, dapat dikerjakan dengan cepat dan hanya membutuhkan spektrofotometer UV-Vis. Prinsip metode uji antioksidan DPPH didasarkan pada reaksi penangkapan hidrogen oleh DPPH dari senyawa antioksidan. DPPH berperan sebagai radikal bebas yang diredam oleh antioksidan dari sampel. Selanjutnya DPPH akan diubah menjadi DPPH-H (bentuk tereduksi DPPH) oleh senyawa antioksidan (Karadag, 2009).

Sebagai langkah awal pengembangan tumbuhan gamal sebagai obat, dibutuhkan uji pendahuluan yang memberikan informasi mengenai aktivitas yang ditimbulkan oleh ekstrak tumbuhan. Untuk itu perlu dilakukan uji atau studi yang berkaitan dengan toksisitas dari tumbuhan gamal. Metode prediksi toksisitas Brine Shrimp Lethality Test (BSLT) umum dilakukan sebagai uji pendahuluan dalam penelitian penapisan aktivitas pada ekstrak bahan alam. 
Brine Shrimp Lethality Test (BSLT) merupakan salah satu metode skrining untuk mengetahui ketoksikan suatu ekstrak ataupun senyawa bahan alam. Uji toksisitas ini dapat diketahui dari jumlah kematian larva A. salina Leach. karena pengaruh ekstrak atau senyawa bahan alam pada konsentrasi yang diberikan (Silva, 2007). Metode ini dilakukan dengan menentukan besarnya nilai $\mathrm{LC}_{50}$ selama 24 jam. Data tersebut dianalisis menggunakan probit analisis untuk mengetahui nilai $\mathrm{LC}_{50}$. Jika nilai $\mathrm{LC}_{50}$ masing-masing ekstrak atau senyawa yang diuji kurang dari $1000 \mu \mathrm{g} / \mathrm{mL}$ maka dianggap menunjukkan adanya aktivitas biologik, sehingga pengujian ini dapat digunakan sebagai skrining awal terhadap senyawa bioaktif yang diduga berkhasiat sebagai antikanker (Ramdhini, 2010).

\section{METODE PENELITIAN}

\section{Bahan}

Simplisia daun Nusa gamal (Gliricidia sepium), etanol, n-heksana, etilasetat, metanol, air suling, pereaksi Dragendroff, pereaksi Mayer, asam klorida pekat, serbuk magnesium, besi(III)klorida, asam asetat glasial asamsulfat pekat, kalium hidroksida, larva udang Artemia salina Leach, air laut dan pereaksi DPPH (1,1-diphenyl-2-picrylhydrazyl).

\section{Peralatan}

Seperangkat alat maserasi, rotary evaporator (BüchirotavaporR-200), timbangan analitik (Precisa XB 220A), tabungreaksi (Pyrex), tangas air(waterbath), labu ukur gelap (Pyrex), pipet tetes (Pyrex), corong (Pyrex), mikropipet, batang pengaduk, kertas Whatmann, aluminium foil, gelas kimia (Pyrex), labu ukur (Pyrex), vial, cawan penguap, kertas saring, corong pisah (Pyrex), wadah penetas, dan lampu 60 watt, tabung reaksi bertutup (Pyrex), mikro pipet, vortexmixer $(H-V M-400)$, kuvet $\left(\right.$ Brand $\left.^{\circledR}\right)$, spektrofotometer UV-Vis (SpectrophotometerDouble Beam Halo DB-209 Dynamica).

\section{Ekstraksi}

Simplisia daun gamal (G. sepium) sebanyak $200 \mathrm{~g}$ dimasukan ke dalam wadah toples kaca dan diberikan cairan etanol sebagai penyari. Direndam simplisia selama 3 hari dan sesekali dilakukan pengadukkan. Proses ekstraksi dilakukan hingga pelarut etanol yang digunakan sebagai penyari jernih. Larutan ekstrak etanol daun gamal (G. sepium) kemudian disaring sehingga diperoleh ekstrak yang bebas residu atau simplisia kasar. Hasil maserasi dipekatkan dengan rotary evaporator dan diangin-anginkan hingga diperoleh ekstrak kental.

\section{Fraksinasi}

Ekstrak etanol yang diperoleh dari hasil maserasi difraksinasi dengan metode cair-cair menggunakan pelarut n-heksan dan etil asetat. Pertama ekstrak kental dilarutkan dalam air kemudian dimasukkan ke dalam corong pisah dan digojok dengan pelarut n-heksan. frakasinasi dilakukan berulang hingga pelarut bening kembali. Setelah selesai fraksinasi dengan pelarut $\mathrm{n}$-heksan kemudian proses fraksinasi dilanjutkan dengan pelarut etil asetat. Hasil fraksinasi kemudian diangin-anginkan hingga diperoleh fraksi kental.

\section{Skrining Fitokimia}

Analisis data metabolit sekunder dilakukan secara deskriptif dengan mengamati perubahan karaterisitik yang terjadi pada ekstrak etanol daun gamal (G. sepium) setelah direaksikan dengan reagen kimia yang sesuai untuk masing-masing pengujian metabolit sekunder. Metabolit sekunder yang diujikan adalah alkaloid, fenolik, tannin, flavonoid, saponin, steroid dan triterpenoid. 


\section{Uji BSLT}

Pengujian BSLT dilakukan dengan menggunakan larva Artemia salina Leach yang telah ditetaskan dalam media air laut selama 48 jam. Pengujian dilakukan pada ekstrak etanol, fraksi n-heksan dan fraksi etil asetat daun gamal. Fraksi dan ekstrak yang sukar larut dalam air laut ditambahkan tween sebagai peningkat kelarutan. Pengujian dilakuakan pada konsentrasi 100, 200, 300, 400, 500 dan 600 ppm. Disiapkan wadah untuk pengujian, untuk masing-masing seri konsentrasi, selanjutnya pada tiap konsentrasi larutan dimasukkan 10 ekor larva Artemia salina. Pengamatan dilakukan selama 24 jam terhadap kematian larva Artemia salina dimana setiap konsentrasi dilakukan tiga kali pengulangan. Ditentukan nilai LC50 dari jumlah kematian larva udang Artemia salina.

\section{Uji Aktivitas Antioksidan}

Dibuat larutan DPPH 40 ppm dalam pelarut metanol. Dilakukan pengujian dengan menggunakan ekstrak etanol, fraksi n-heksan dan fraksi etil asetat daun gamal dengan lima variasi konsentrasi yaitu konsentrasi 100, 150, 200, 250 dan 300 ppm. larutan ekstrak-DPPH kemudian diinkubasi selama 30 menit. Dilakukan pengukuran absorbansi dengan menggunakan spektrofotometer UV-Vis pada panjang gelombang $515.5 \mathrm{~nm}$. Dilakukan replikasi sebanyak 3 kali untuk setiap variasi konsentrasi. Ditentukan nilai IC $_{50}$ dari ekstrak dengan terlebih dahulu menentukan presentase peredaman DPPH.

\section{HASIL DAN PEMBAHASAN}

Sampel diperoleh dari Kecamatan Kongbeng Kabupaten Kutai Timur, Kalimantan Timur. Sebanyak $200 \mathrm{~g}$ simplisia daun gamal kering dimaserasi dengan menggunakan pelarut etanol. Dari hasil maserasi menggunakan etanol diperoleh ekstrak kental sebanyak 49,4 g dengan nilai rendemen sebesar $24,7 \%$. Sebanyak $30 \mathrm{~g}$ ekstrak etanol difraksinasi menggunakan pelarut $\mathrm{n}$-heksan dan etil asetat. Diperoleh fraksi $\mathrm{n}$-heksan sebanyak $8,9 \mathrm{~g}$ dengan nilai rendemen $28,6 \%$ dan fraksi etil asetat sebanyak 2,3 g dengan nilai rendemen $7,6 \%$.

Tabel 1. Kandungan metabolit sekunder ekstrak dan fraksi daun gamal

\begin{tabular}{lcccccc}
\hline \multicolumn{1}{c}{ Sampel } & Alkaloid & Fenolik & Tanin & Flavonoid & Saponin & Steroid \\
\hline Ekstrak etanol & + & + & + & - & + & + \\
Fraksi n-heksan & + & - & - & - & - & + \\
Fraksi etil asetat & + & + & + & - & + & - \\
\hline
\end{tabular}

Skrining fitokimia atau uji metabolit sekunder adalah metode analisis kandungan metabolit sekunder pada suatu bahan secara kualitatif. Analisis metabolit sekunder pada penelitian ini dilakukan terhadap daun tanaman gamal yang telah dimaserasi menggunakan pelarut etanol dan fraksi n-heksan serta fraksi etil asetat. Pengujiannya dilakukan dengan cara menguji sedikit sampel dari ekstrak dan fraksi tersebut, lalu ditambahkan reagen sesuai dengan senyawa yang akan diidentifikasi. Senyawa-senyawa yang diperiksa keberadaannya adalah alkaloid, fenolik, flavonoid, tanin, saponin dan steroid atau triterpenoid. Hasil skrining metabolit sekunder seperti ditunjukan pada gambar 1 diperoleh bahwa pada ekstrak etanol daun gamal positif mengandung metabolit sekunder golongan alkaloid, fenolik, tanin, saponin dan steroid. Pada fraksi n-heksan positif mengandung metabolit sekunder golongan alkaloid dan steroid. Pada fraksi etil asetat positif mengandung senyawa metablit sekunder golongan alkaloid, fenolik, tanin dan saponin. 


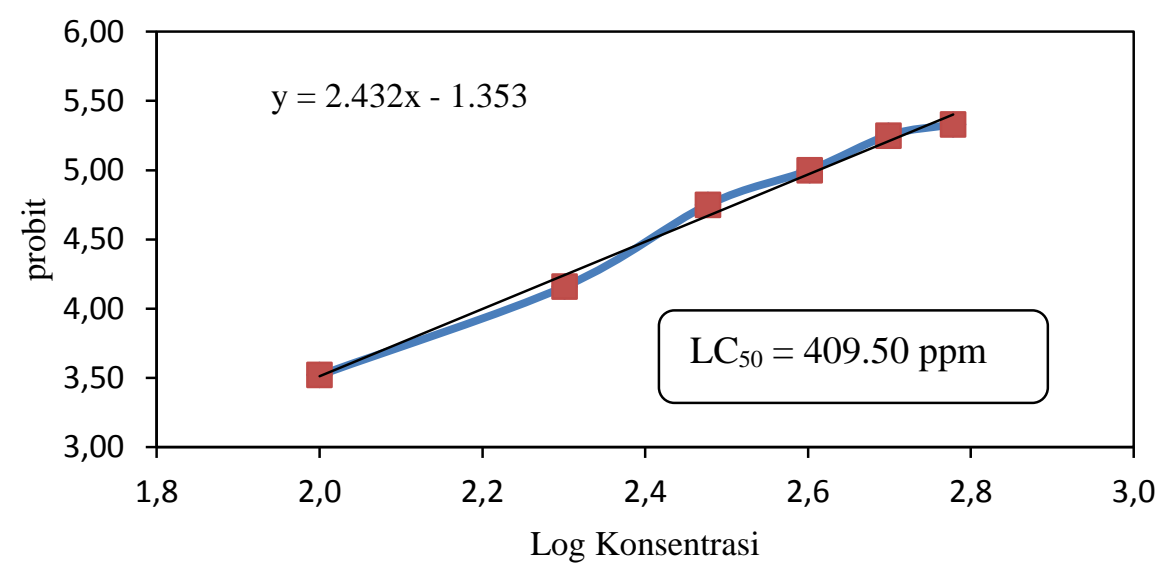

Gambar 1 : Toksisitas ekstrak etanol daun G. sepium terhadap larva A. salina

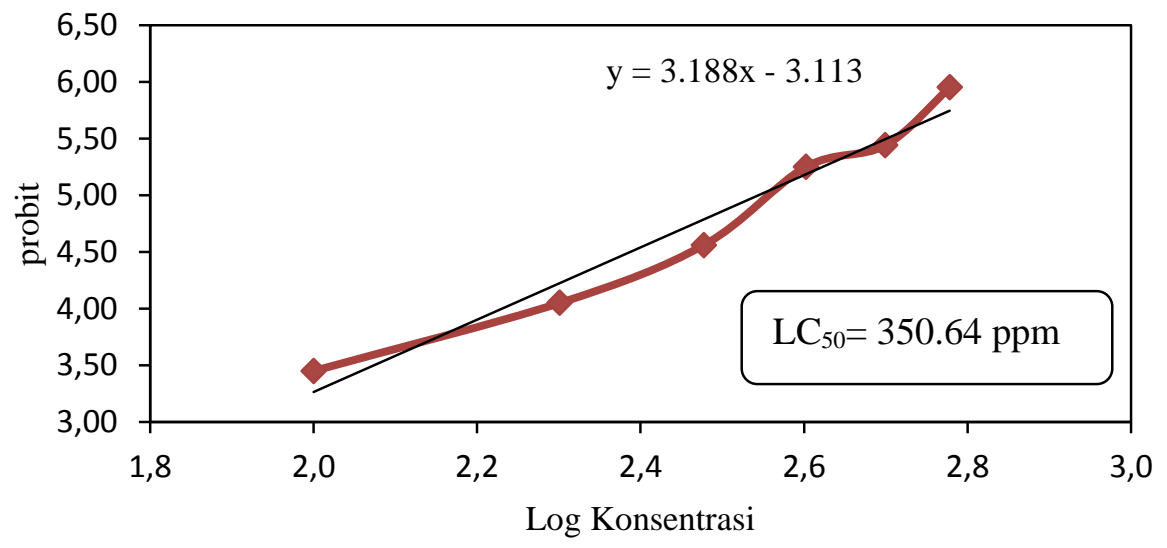

Gambar 2 : Toksisitas fraksi n-heksan daun G. sepium terhadap larva A. salina

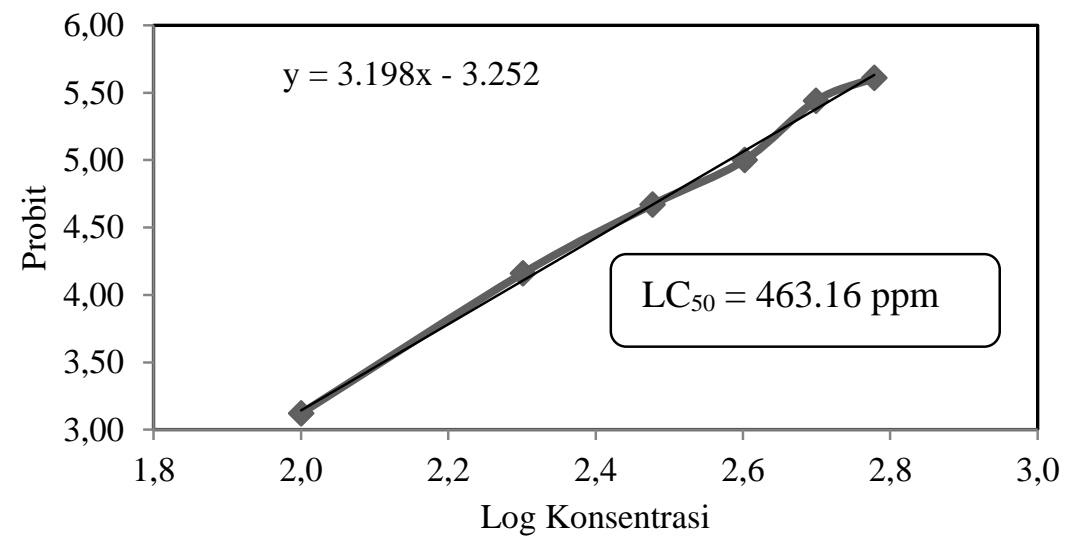

Gambar 3 :Toksisitas fraksi etil asetat daun G. sepium terhadap larva A. salina 
Brine Shrimp Lethality Test (BSLT) merupakan salah satu metode skrining untuk mengetahui ketoksikan suatu ekstrak ataupun senyawa bahan alam. Uji toksisitas ini dapat diketahui dari jumlah kematian larva A. salina Leach. karena pengaruh ekstrak atau senyawa bahan alam pada konsentrasi yang diberikan. Metode ini dilakukan dengan menentukan besarnya nilai $\mathrm{LC}_{50}$ selama 24 jam. Data tersebut dianalisis menggunakan probit analisis untuk mengetahui nilai $\mathrm{LC}_{50}$. Jika nilai $\mathrm{LC}_{50}$ masing-masing ekstrak atau senyawa yang diuji kurang dari 1000 ppm, maka dianggap menunjukkan adanya aktivitas biologik. Pada pengujian ini dilakukan penambahan tween sebagai peningkat kelarutan karena ekstrak dan fraksi yang sedikit sukar larut dalam air laut. Pengujian toksisitas ekstrak daun gamal dengan metode BSLT dimana pada pengujiannya menggunakan enam variasi konsentrasi yaitu 100, 200, 300, 400, 500 dan 600 ppm dengan pengulangan sebanyak 3 kali pada setiap variasi konsentrasi. Kontrol dibuat dengan memberikan perlakuan yang sama terhadap larva udang namun tanpa penambahan ekstrak uji. Pada kontrol juga ditambahkan tween dengan maksud menyamakan kondisi dan perlakuan seperti pada kelompok uji sehingga hasil yang diperoleh dapat dianalisa bahwa kematian larva udang yang terjadi pada kelompok uji bukan disebabkan oleh adanya penambahan peningkat kelarutan melainkan karena efek dari penambahan ekstrak daun gamal. Hasil dari pengujian toksisitas akut daun gamal terhadap larva Artemia salina pada ekstrak etanol ditunjukkan pada gambar 2 dimana grafik kematian larva udang menunjukkan nilai $\mathrm{LC}_{50}$ ekstrak tersebut adalah 409,5 ppm. Toksisitas fraksi nheksan daun gamal ditunjukkan pada gambar 3 dengan nilai $\mathrm{LC}_{50}$ sebesar 350,64 ppm. Toksisitas dari fraksi etil asetat ditunjukkan pada gambar 4 dengan nilai $\mathrm{LC}_{50}$ sebesar 463,16 ppm. Nilai $\mathrm{LC}_{50}$ pada hasil uji menunjukkan konsentrasi dimana ekstrak tersebut dapat membunuh sebanyak 50\% hewan atau larva uji. Sehingga dapat dinyatakan bahwa daun gamal mempunyai aktifitas biologik dimana nilai $\mathrm{LC}_{50}$ berada lebih rendah dari 1000 ppm.

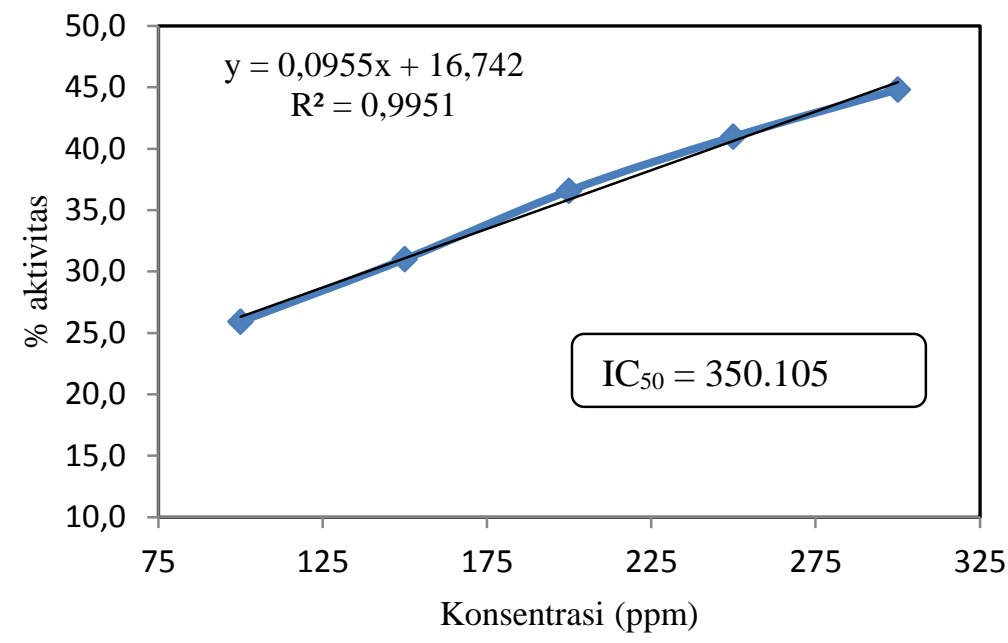

Gambar 4 : Aktivitas antioksidan ekstrak etanol daun G.sepium terhadap peredaman radikal DPPH

Uji aktivitas antioksidan dari ekstrak daun gamal (G. sepium ) dilakukan melalui reaksi peredaman radikal 2,2-diphenyl-1-picrylhydrazyl (DPPH). Radikal bebas dikenal sebagai faktor utama dalam kerusakan biologi, dan DPPH digunakan untuk mengevaluasi aktivitas peredaman radikal bebas dari suatu antioksidan alami. DPPH yang merupakan suatu molekul radikal bebas dengan warna ungu dapat berubah menjadi senyawa yang stabil 
dengan warna kuning oleh reaksi dengan antioksidan, dimana antioksidan memberikan satu elektronnya pada DPPH sehingga terjadi peredaman pada radikal bebas DPPH. Uji DPPH merupakan metode yang mudah untuk menapis sejumlah kecil molekul antioksidan karena reaksi dapat diamati secara visual menggunakan KLT, atau juga intensitasnya dapat dianalisis melalui spektrofotometri sederhana. Elektron tak berpasangan pada DPPH memberikan suatu absorbsi yang kuat, pada panjang gelomabang maksimum $\lambda=515.5 \mathrm{~nm}$ dan berwarna ungu. Peredaman radikal bebas oleh antioksidan terjadi ketika elektron tak berpasangan menjadi berpasangan dengan adanya sebuah donor hidrogen, sehingga membentuk DPPH yang lebih stabil.

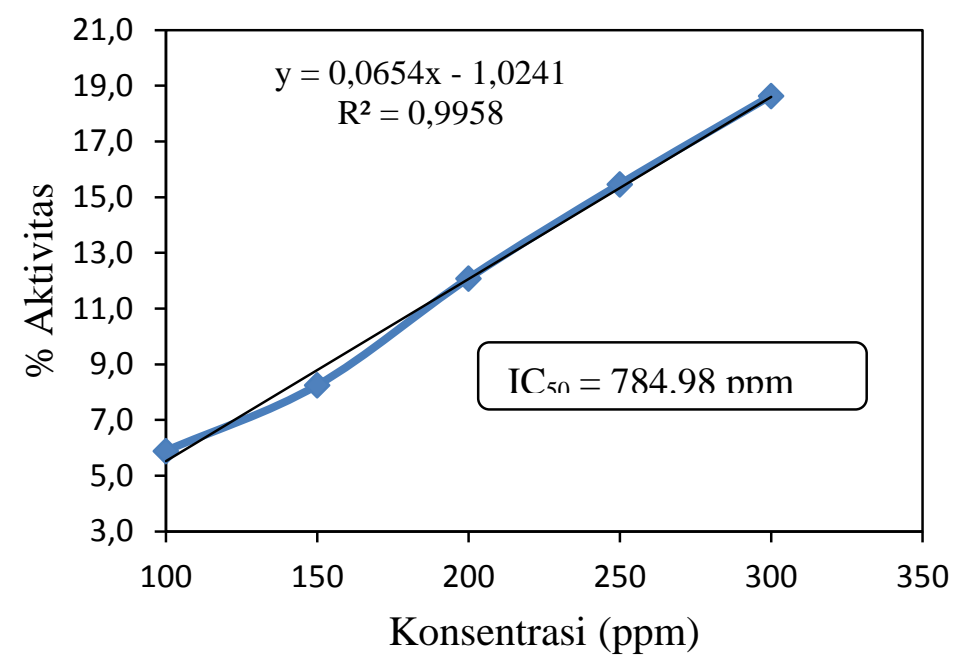

Gambar 6 : Aktivitas antioksidan fraksi n-heksan daun G.sepium terhadap peredaman radikal DPPH

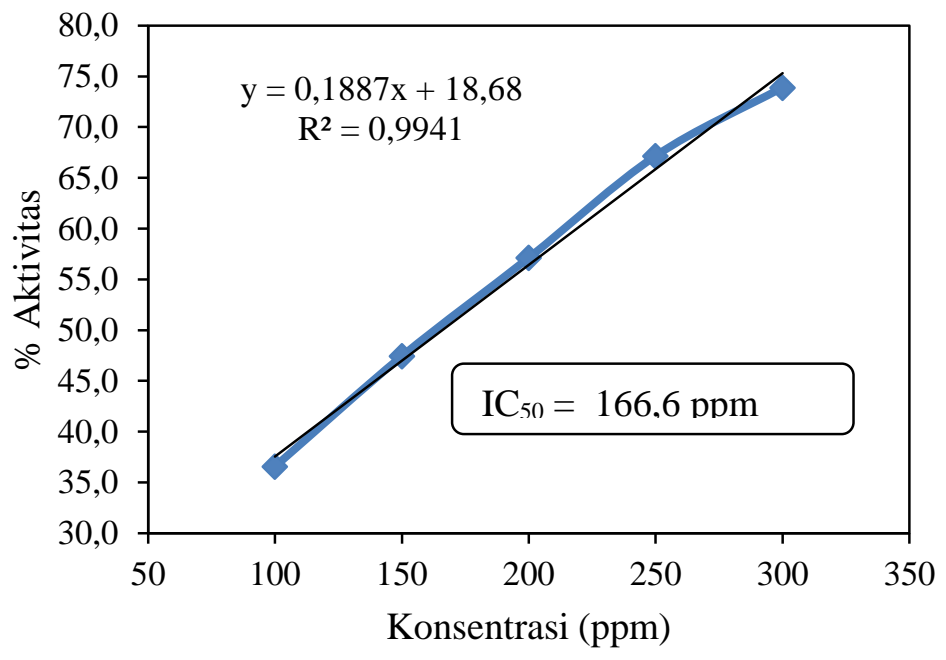

Gambar 7 : Aktivitas antioksidan fraksi etil asetat daun G.sepium terhadap peredaman radikal DPPH 
Peredaman radikal oleh senyawa antioksidan umumnya disebut dengan inhibisi, sedangkan besarnya peredaman dinyatakan dalam persen inhibisi. Penentuan konsentrasi aktivitas antioksidan dilakukan dengan menentukan nilai $\mathrm{IC}_{50}$ (Inhibitory Concentration) atau besarnya konsentrasi senyawa yang diduga beraktivitas sebagai antioksidan terhadap peredaman radikal DPPH. Pengujian aktivitas antioksidan daun gamal dilakukan dengan lima variasi konsentrasi dengan masing-masing 3 replikasi setiap konsentrasinya. Blanko digunakan dengan menggunakan larutan DPPH dan penambahan pelarut metanol sesuai dengan penggunaan pelarut pada larutan ekstrak.

Senyawa bahan alam yang diyakini mempunyai aktivitas sebagai antioksidan adalah senyawa fenolik ataupun polifenol pada flavonoid. Pada senyawa polifenol, aktivitas antioksidan berkaitan erat dengan struktur rantai samping dan juga substitusi pada cincin aromatiknya. Kemampuannya untuk bereaksi dengan radikal bebas DPPH dapat mempengaruhi urutan kekuatan antioksidannya. Aktivitas peredaman radikal bebas senyawa polifenol diyakini dipengaruhi oleh jumlah dan posisi hidrogen fenolik dalam molekulnya. Dengan demikian aktivitas antioksidan yang lebih tinggi akan dihasilkan pada senyawa fenolik yang mempunyai jumlah gugus hidroksil yang lebih banyak pada inti flavonoidnya. Senyawa fenolik ini mempunyai kemampuan untuk menyumbangkan hidrogen, maka aktivitas antioksidan senyawa fenolik dapat dihasilkan pada reaksi netralisasi radikal bebas yang mengawali proses oksidasi atau pada penghentian reaksi radikal berantai yang terjadi. Senyawa alkaloid, terutama indol, memiliki kemampuan untuk menghentikan reaksi rantai radikal bebas secara efisien. Senyawa radikal turunan dari senyawa amina ini memiliki tahap terminasi yang sangat lama.

Hasil pengujian aktivitas antioksidan daun gamal terhadap peredaman radikal DPPH diperoleh nilai IC $_{50}$ dari ekstrak etanol daun gamal adalah 350,105 ppm (gambar 5) pada fraksi nheksan nilai $\mathrm{IC}_{50}$ sebesar 784,98 ppm (gambar 6) dan pada fraksi etil asetat diperoleh nilai $\mathrm{IC}_{50}$ sebesar 166,6 ppm (gambar 7). Dari data tersebut dapat disimpulkan bahwa aktivitas antioksidan daun gamal pada ekstrak etanol adalah sangat rendah, pada fraksi n-heksan sangat buruk atau cenderung tidak memiliki aktivitas yang signifikan terhadap peredaman radikal DPPH dan pada fraksi etil asetat memiliki aktivitas antioksidan kuat. Hasil ini dapat dikaitkan dengan kandungan metabolit sekunder yang terkandung dalam daun gamal yang mana telah diuji sebelumnya. Pada ekstrak etanol mempunyai aktivitas antioksidan yang kemungkinan disebabkan kandungan senyawa alkaloid dan fenolik sebagai senyawa peredam radikal. Walaupun begitu aktivitas antioksidan yang ditunjukkan oleh ekstrak etanol sangat lemah hal ini dimungkinkan terdapat senyawa lain yang dominan namun tidak memiliki aktivitas antioksidan seperti masih terdapatnya klorofil dari daun gamal sehingga peredaman yang diperoleh sangat rendah. Pada fraksi n-heksan ditunjukkan hasil yang tidak signifikan bahkan hampir sama sekali tidak memiliki aktivitas antioksidan terhadap peredaman DPPH. Hal ini disebabkan pada fraksi n-heksan hanya terdapat senyawa golongan alkaloid dan steroid yang kurang memiliki aktivitas sebagai peredam radikal atau antioksidan. Hasil uji antioksidan oleh fraksi etil asetat menunjukan rentang sedang dengan nilai $\mathrm{IC}_{50} 166,6 \mathrm{ppm}$. Hal ini dapat disebabkan adanya senyawa fenolik pada fraksi etil asetat yang berperan aktif sebagai antioksidan dari radikal DPPH.

\section{KESIMPULAN}

Toksisitas paling tinggi terdapat pada fraksi n-heksan dengan nilai $\mathrm{LC}_{50} 350.63$ ppm dan aktivitas antioksidan paling aktif terdapat pada fraksi etil asetat dengan nilai IC $_{50}$ 166,6 ppm.

\section{DAFTAR PUSTAKA}

Green, R.J., 2004, Antioxidant Activity of Peanut Plant Tissues. Thesis. North Caroline State University. Department of Food Science, Raleigh.

Karadag, A., Ozcelik, B. and Saner, S., 2009, Review of Methods to Determine Antioxidant Capacities. Food Anal. Methods. 2. 41-60. 
Orwa C., Mutua A., Kindt R.S, Jamnadass R., dan Anthony S., 2009, Agroforestree Database: a tree reference and selection guide version 4.0. World Agroforestry Centre. Kenya.

Ozyurt M, Tekgunduz A, Karagoz B, Bilgis O, Bilekli F., 2008, Febril neutropenia etiology in a hematology department. Europe Journal General Medicine Vol. 5(4); 228-231.

Ramdhini, R. N., 2010, Uji Toksisitas Terhadap Artemia Salina Leach. dan Toksisitas Akut Komponen Bioaktif Pandanus Conoideus Var. Conoideus Lam. sebagai Kandidat Antikanker. Thesis. Universitas Sebelas Maret Surakarta.

Setiana, A., 2011, Pembentukan Senyawa Alkaloid Dan Terpenoid. Universitas Muhammadiyah. Sukabumi.

Yuhernita dan Juniarti. 2011, Analisis Senyawa Metabolit Sekunder Dari Ekstrak Metanol Daun Surian Yang Berpotensi Sebagai Antioksidan. Jurnal Makara Sains, vol. 15, no. 1: 48-52. 